\title{
Studies on Effect of Hormone on in vitro Regeneration of Tinospora cordifolia
}

\author{
Anika Malik* and Aditi Arya \\ Department of Biotechnology (Plant Tissue Culture and Genetic Engineering Lab), \\ Deenbandhu Chhoturam University of Science and Technology, Murthal, \\ Sonipat, Haryana, India, 131001 \\ *Corresponding author
}

\section{A B S T R A C T}

Keywords

Tinospora

cordifolia,

Micropropagation,

Explants, BAP,

IAA

Article Info

Accepted:

12 September 2019

Available Online:

10 October 2019
Research in plant biotechnology is playing a crucial role in the production and conservation of plant-based resources globally. The aim of the work was to establish favourable culture medium condition for regeneration and better growth of Tinospora cordifolia explant. Plant Micropropagation has also been used as a tool for the propagation of genetically manipulated superior clones. Our attempt was made to develop micropropagation as suitable condition for cloning of Tinospora cordifolia. The explants were cut into desirable size and inoculated into regeneration medium consisting of Murashige and Skoog basal combination and various combinations of hormones. The cultures were incubated at 16:8 hrs photoperiod and temperature of $27+2^{\circ}$. Nodal explants produced proliferation of shoots on the medium containing nodal explants produced proliferation of shoots on the medium containing BAP and IAA at different combinations. Results were obtained showing regeneration frequency after 14 and 21 days.

\section{Introduction}

Medicinal plants are considered as green gold inferable from their significant commitment to the medicinal services and prosperity of human social orders. The utilization of customary medication and therapeutic plants in most developing nations, as a standardizing reason for the upkeep of good wellbeing, has been generally watched. Drugs in India are utilized by around 60 percent of total populace. It is estimated that about 80,000 species of plants are utilized in various forms other by the different system of India medicine. India has a rich biodiversity of the restorative plants that are as yet not investigated totally. The requirement for the novel pharmaceutical items out from the 
plants has achieved an incredible enthusiasm for the present research world because of the expense and the higher reactions that are related with the synthetically made medications.

Many medicinal plant species are disappearing at an alarming rate, as a result of rapid agricultural and urban development, deforestation and indiscriminate collections. If this trend continues, man kind will loss some of the most important sources of drugs. Tinospora cordifoliais one of those species. Tinospora cordifolia (Willd.) Miers ex Hook. F. \& Thoms is an important medicinal climber, commonly called as Giloy is found in tropical regions of India, China, Sri Lanka, and Bangladesh (Mittal et al., 2014). Besides, it is rich with a variety of natural chemical constituent's viz., tinosporin, cordifolioside, magnoflorine, palmetine, isocolumbin, tinocordiside, glycoside, cordifolioside syringing (Nagarkar et al., 2013; Choudhry et al.,2014) and cures a number of ailments such as viral infections, cancer, diabetes, inflammation, neurological disorders, psychiatric problems, microbial infection, hyper tension and HIV aids (Jayaganthan et al., 2013; Nagarkar et al., 2013; Joladarash et al., 2014; Mittal et al., 2014). This plant species has been listed in prioritized medicinal plants of 8 agriculture climatic zones by National Medicinal Plant Board (NMPB), New Delhi, India. Recently, this plant species has extensively been used to cure chikungunya and dengue. Many ayurvedic pharmaceutical industries are producing medicines using Giloy to cure diseases like arthritis, skin diseases (psoriasis). But over exploitation has led to the acute scarcity of this plant to meet the present daydemands. Because of its medicinal use, it's conservation and varietal improvement through various strategies like tissue culture, agroforestry, genetic engineering and reproductive biological techniques is paramount.
Advancement of plant tissue culture innovation offers an incredible potential for fast increase of plant germplasm. It fulfils in as an integral asset for short to medium term protection of significant plant species. Tissue culture innovation gives a perfect method to enormous scale engendering and the reintroduction of the plants in its common natural surroundings. In vitro spread expands the effectiveness and scales up plant generation. Also, plant cell and tissue culture, just as hereditary building might be an option in contrast to the customary strategy for the improvement of medicinal plants. The in vitro societies could be protected extra time and increased as and when required. Tissue culture additionally encourages the trading of germplasm inside and over the nations. In our research main objective was to optimize the sterilisation time and to standardize the media concentration for regeneration of Tinospora cordifolia from different explants using different plant growth regulators.

\section{Materials and Methods}

\section{Plant material}

The explants of Tinospora cordifolia for the present study were taken from a known identified variety. Explants used for in vitro culture were prepared from Nodal segments, Internodes.

\section{Chemicals}

All the chemicals used in the present study were of analytical grade and were procured from $\mathrm{Hi}$ media India limited and Merck chemicals, Pvt. Ltd.

\section{Sterilisation}

Young nodal segments and internodes were collected as explants from healthy plants of $T$. cordifolia and brought to the laboratory in wet 
polythene bags. The explants were excised to appropriate size and explants of about $2 \mathrm{~cm}$ size were chosen. Excised explants were first washed with detergent (tween20/tween80) for 7-10 minutes followed by repeated washing in distilled water in order to remove any remaining detergent. Then, the explants were treated with $0.1 \% \mathrm{Hgcl}_{2}$ for different duration, followed by washing with double distilled sterilized water in laminar air flow for further use.

\section{Culture media}

Murashige and Skoog (MS) basal medium was used for the study. All the media was prepared in double distilled water. Stock solutions of micro and macro nutrients were prepared.

Addition of $0.8 \%$ agar- agar in medium for solidification and the $\mathrm{pH}$ of medium was adjusted to 5.7-5.8 with1N HCL and $0.1 \mathrm{~N}$ $\mathrm{NaOH}$.

The media was poured in flasks which were sterilized in an autoclave at $121^{\circ} \mathrm{C}$ at $15 \mathrm{psi}$ for 15 mins and stored at room temperature at \pm $1^{0} \mathrm{C}$ for further use. Different concentration of BAP and IAA were used to study the survival and regeneration percentage.

\section{Plant growth regulators}

Stock solution of different growth regulators, such as cytokinins and auxins were prepared for regular use and stored at $4^{0} \mathrm{C}$. The medium was supplemented with different concentration of cytokine and auxin individually as well as in combination with each other.

\section{Inoculation}

Sterilized explants were inoculated on sterilized media under aseptic condition in laminar air flow. Three to four explants were inoculated per flask.

\section{Culture conditions}

All the culture flasks were placed under controlled condition i.e. light and temperature in a culture room pre-fitted with photoperiodic controller and sequential timer. Temperature was maintained at $25^{\circ} \mathrm{C}+/-2^{0} \mathrm{C}$ and the light intensity of 1000 lux was provided and was fixed at about16-18 hours.

\section{Growth of regenerated plantlets}

The regenerated explants in all the experiments were reported and the subculturing of regenerated plants was done by transferring on MS medium supplemented with same concentration of growth regulators for multiplication in vitro. Each set of the experiment was repeated thrice with three replicates with the same hormone concentrations.

\section{Results and Discussion}

The present investigation was conducted with an objective to develop an efficient in vitro regeneration protocol for T.cordifolia species. The experiment was conducted in the Plant Biotechnology Lab of Department of Biotechnology, Deenbandhu Chhoturam University of Science and Technology.

\section{Sterilisation}

To standardize the ideal sterilization time, $0.1 \% \mathrm{Hgcl}_{2}$ was used and the explants were exposed to this sterilizing agent for varying durations.

The in vitro establishment of T.cordifolia Cultures from nodal explants was assessed with the number of explants which got contaminated. It indicates that the highest percentage of contamination $(60 \%)$ was found when the explants were treated with $\mathrm{Hgcl}_{2}$ $(0.1 \%)$ for 2 minutes. The contamination 
percentage was reduced to $5 \%$ with $\mathrm{Hgcl}_{2}$ $(0.1 \%)$ for 4 minutes. At 6 minutes of exposure with $\mathrm{Hgcl}_{2}(0.1)$, most of the explants turned brown and black as shown in table 1 . Hence $\mathrm{Hgcl}_{2}$ concentration of $0.1 \%$ at 4 minutes was considered best for sterilization and this sterilization time and concentration was also used for subsequent regeneration experiment.

The explant (nodes and internodes) were selected from plants of. T.cordifolia and sterilization of explants was done by $0.1 \%$ $\mathrm{HgCl}_{2}$ for 4 min and then inoculated on MS media containing varying concentration of BAP.

Table 2 showed that in table from (1-5) was the in vitro regeneration of shoots from nodes of T.cordifolia and from (6-10) was the in vitro regeneration of shoots from internodes of T.cordifolia on basal media MS containing various concentration $\mathrm{BAP}(\mathrm{MS}+1-5 \mathrm{mg} / \mathrm{l})$ and IAA (MS +1.0 to $5.0 \mathrm{mg} / \mathrm{l}$ ), it was found that nodes of T.cordifolia showed highest regeneration frequency of $54 \%$ at $1.0 \mathrm{mg} / \mathrm{l}$ concentration of BAP after $14^{\text {th }}$ day and $81 \%$ after $21^{\text {st }}$ days and where internodes showed highest regeneration frequency of $65 \%$ at 1.0 $\mathrm{mg} / \mathrm{l}$ concentration of IAA after 14th day and $71 \%$ after 21 st days respectively.

Table 3 showed the in vitro regeneration of shoots from nodes of T.cordifolia on basal media MS containing varying concentration of BAP $(0.5-2.50 \mathrm{mg} / \mathrm{l})$ and IAA $1.00 \mathrm{mg} / \mathrm{l}$ (constant) from (1-5) and it was found that nodes of T.cordifolia show highest regeneration frequency of $70 \%$ at $1.00 \mathrm{mg} / \mathrm{l}$ concentration of IAA and $1.5 \mathrm{mg} / \mathrm{l}$ of BAP after $14^{\text {th }}$ day and $77 \%$ after $21^{\text {st }}$ day. Also showed least regeneration frequency of $40 \%$ at $0.5 \mathrm{mg} / \mathrm{l} \mathrm{BAP}$ and $1.5 \mathrm{mg} / \mathrm{l} \mathrm{IAA}$ after $14^{\text {th }}$ days and $45 \%$ after 21 st day. Whereas, the in vitro regeneration of shoots from internodes of T.cordifolia on basal media MS containing varying concentration of IAA $(0.5$ to $3.0 \mathrm{mg} / \mathrm{l})$ and BAP $1.0 \mathrm{mg} / 1$ (constant) from (6-10) and it was found that internodes of T.cordifolia showed highest regeneration frequency of $77 \%$ at $1.0 \mathrm{mg} / \mathrm{l} \mathrm{BAP}$ and $2.0 \mathrm{mg} / \mathrm{t} \mathrm{IAA}$ after $14^{\text {th }}$ days and $78 \%$ after 21 days. Also showed least regeneration frequency of $64 \%$ at $1.0 \mathrm{mg} / \mathrm{l} \mathrm{BAP}$ and $3.0 \mathrm{mg} / \mathrm{l} \mathrm{IAA}$ after $14^{\text {th }}$ days and $64 \%$ after $21^{\text {st }}$ days (Fig. 1).

Table.1 Effect of sterilization agent on explants (nodes and internodes) at different duration.

\begin{tabular}{|c|c|c|c|c|c|}
\hline S.no & $\begin{array}{c}\text { Sterilizing } \\
\text { agent }\end{array}$ & $\begin{array}{c}\text { Concentration } \\
(\mathbf{\%})\end{array}$ & $\begin{array}{c}\text { Duration of } \\
\text { exposure (in } \\
\text { minutes) }\end{array}$ & $\begin{array}{c}\text { \% } \\
\text { contamination } \\
\text { observed } \\
\text { (nodes) }\end{array}$ & $\begin{array}{c}\text { \% } \\
\text { contamination } \\
\text { observed } \\
\text { (internodes) }\end{array}$ \\
\hline $\mathbf{1}$ & $\mathrm{HgCl}_{2}$ & 0.1 & 2 & 68 & 60 \\
\hline $\mathbf{2}$ & $\mathrm{HgCl}_{2}$ & 0.1 & 3 & 50 & 55 \\
\hline $\mathbf{3}$ & $\mathrm{HgCl}_{2}$ & 0.1 & 4 & 8 & 15 \\
\hline $\mathbf{4}$ & $\mathrm{HgCl}_{2}$ & 0.1 & 5 & Turned brown & Turned brown \\
\hline $\mathbf{5}$ & $\mathrm{HgCl}_{2}$ & 0.1 & 6 & Turned brown & Turned black \\
\hline
\end{tabular}


Table.2 Effect of varying concentration of BAP and IAA on regeneration of shoots

\begin{tabular}{|c|c|c|c|c|c|}
\hline S.no & $\begin{array}{c}\text { BAP } \\
\text { Concentration } \\
(\mathbf{m g} / \mathbf{l})\end{array}$ & $\begin{array}{c}\text { IAA } \\
\text { concentration } \\
(\mathbf{m g} / \mathbf{l})\end{array}$ & Media code & $\begin{array}{c}\text { \% } \\
\text { regeneration } \\
\text { frequency of } \\
\text { shoots from } \\
\text { nodes after 14 } \\
\text { days }\end{array}$ & $\begin{array}{c}\text { \% } \\
\text { regeneration } \\
\text { frequency of } \\
\text { shoots from } \\
\text { nodes after 21 } \\
\text { days }\end{array}$ \\
\hline $\mathbf{1}$ & 1.0 & & B1 & 54 & 81 \\
\hline $\mathbf{2}$ & 2.0 & & B2 & 51 & 78 \\
\hline $\mathbf{3}$ & 3.0 & & B3 & 49 & 75 \\
\hline $\mathbf{4}$ & 4.0 & & B4 & 45 & 68 \\
\hline $\mathbf{5}$ & 5.0 & & B5 & 42 & 65 \\
\hline $\mathbf{6}$ & & 1.0 & B6 & 65 & 71 \\
\hline $\mathbf{7}$ & & 2.0 & B7 & 59 & 55 \\
\hline $\mathbf{8}$ & & 3.0 & B8 & 58 & 67 \\
\hline $\mathbf{9}$ & & 4.0 & B9 & 61 & 51 \\
\hline $\mathbf{1 0}$ & & 5.0 & B10 & 65 & 69 \\
\hline
\end{tabular}

Table.3 (1-5) Effect of IAA and varying concentration of BAP, (6-10) Effect of BAP and varying concentration of IAA.

\begin{tabular}{|c|c|c|c|c|c|}
\hline S.no & $\begin{array}{c}\text { BAP } \\
\text { concentration } \\
(\mathbf{m g} / \mathbf{l})\end{array}$ & $\begin{array}{c}\text { IAA } \\
\text { concentration } \\
(\mathbf{m g} / \mathbf{l})\end{array}$ & Media code & $\begin{array}{c}\text { \% } \\
\text { regeneration } \\
\text { frequency of } \\
\text { shoots from } \\
\text { nodes after 14 } \\
\text { days }\end{array}$ & $\begin{array}{c}\text { \% } \\
\text { regeneration } \\
\text { frequency of } \\
\text { shoots from } \\
\text { nodes after 21 } \\
\text { days }\end{array}$ \\
\hline $\mathbf{1}$ & & & & 40 & 45 \\
\hline $\mathbf{2}$ & 0.5 & 1.0 & $\mathrm{~A} 1$ & 70 & 77 \\
\hline $\mathbf{3}$ & 1.0 & 1.0 & $\mathrm{~A} 2$ & 60 & 63 \\
\hline $\mathbf{4}$ & 1.5 & 1.0 & $\mathrm{~A} 3$ & 55 & 56 \\
\hline $\mathbf{5}$ & 2.0 & 1.0 & $\mathrm{~A} 4$ & 68 & 72 \\
\hline $\mathbf{6}$ & 2.5 & 1.0 & $\mathrm{~A} 5$ & 73 & 78 \\
\hline $\mathbf{7}$ & 1.0 & 0.5 & $\mathrm{~B} 11$ & 68 & 75 \\
\hline $\mathbf{8}$ & 1.0 & 1.0 & $\mathrm{~B} 12$ & 75 & 70 \\
\hline $\mathbf{9}$ & 1.0 & 2.0 & $\mathrm{~B} 13$ & 68 & 72 \\
\hline $\mathbf{1 0}$ & 1.0 & 2.5 & $\mathrm{~B} 14$ & 62 & 64 \\
\hline
\end{tabular}


Fig.1 In vitro regeneration of shoots from nodes (A) and internodes (C) of Tinospora cordifolia after 14th day, and in vitro regeneration of shoots from nodes (B) and internodes (D) of

Tinospora cordifolia after 21 th day

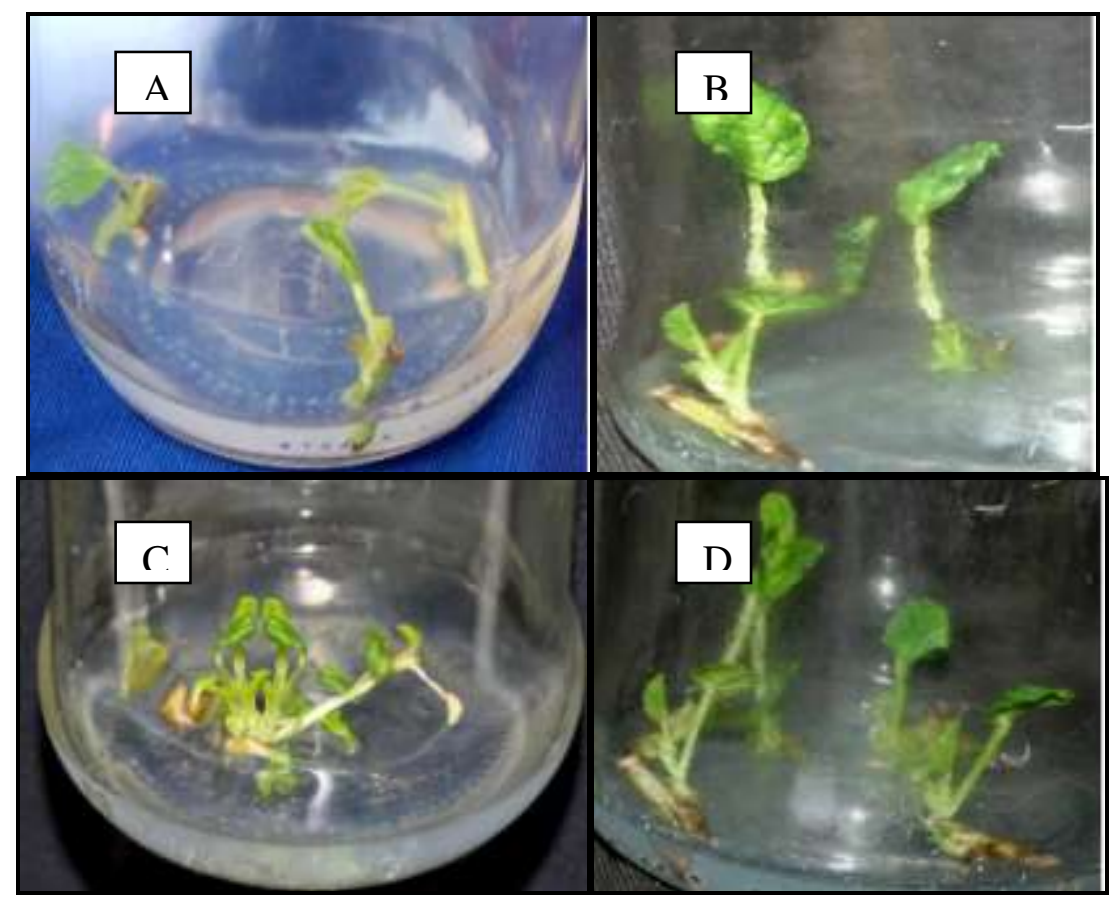

Tinospora cordifolia is propagated by both seeds and vegetative means. There is a huge demand of planting material. In recent years, the technique of micro propagation has been used to produce clones of many economical plants, restoration of vigour and yield due to infection and preservation of germplasm. Hence tissue culture is a very useful tool for the production of planting material.

Micropropagation alludes to the fast clonal proliferation of plants through tissue culture and explicitly includes developing plant cells, tissues, organs, seeds or other plant parts in a sterile domain on a proper supplement medium. In vitro propagation involves application to a large number of species, many of which are important horticulture plants.

In this background, attempts were made to study the in vitro propagation of T.cordifolia species. Nodes and internodes were used as explants and cultured on MS medium supplemented with different hormonal combinations of BAP \& IAA. The duration of sterilization time was also standardized.

The maximum efficient sterilization time of $\mathrm{HgCl}_{2}(0.1 \%)$ treatment was 4 minutes which showed the least contamination. The maximum regeneration frequency of nodes with BAP was observed to be $60 \%$ after $14^{\text {th }}$ day and $68 \%$ after 21 days of inoculation whereas, maximum regeneration frequency of nodes with IAA was observed to be $65 \%$ after 14 days and $75 \%$ after 21 days of inoculation.

In addition maximum regeneration frequency of nodes with IAA $1.0 \mathrm{mg} / \mathrm{l}$ (constant) and BAP $(0.5-2.5 \mathrm{mg} / \mathrm{l})$ was found to be $70 \%$ after 14 days $\& 77 \%$ after 21 days of inoculation on the other hand maximum regeneration frequency of internodes with IAA (0.5-3.0 $\mathrm{mg} / \mathrm{l}$ ) and BAP $0.5 \mathrm{mg} / \mathrm{l}$ (constant) was found 
to be $77 \%$ after 14 days \& $79 \%$ after 21 days of inoculation.

\section{Acknowledgement}

This work was ostensibly supported by the Department of Biotechnology, Deenbandhu Chhoturam University of science and technology, Murthal.

\section{References}

Briskin, D.P. 2000. Medicinal Plants and Phyto medicines, Linking Plant Biochemistry and Physiology to Human Health. American Society of Plant Physiology. 124(2): 507-514.

Chaudhari, S., and Shaikh, N.2013. Gaduchithe best ayurvedic herb. The Pharma Innovation Journal. 2(4):97-102.

Chee, M. J. Y., Lycett, G. W., and Chin, C. F. 2018. Development of a direct transformation method by GFP screening and in vitro whole plant regeneration of Capsicum frutescens L. Electronic Journal of Biotechnology. 34: 51-58.

Chiruvella, K. K., Mohammed, A., Dampuri, G., and Ghana, R. G. 2012. In vitro Shoot Regeneration and Control of Shoot Tip Necrosis in Tissue Cultures of Soymida febrifuga (Roxb.) A. Juss. Plant Tissue Cult. \& Biotech. 21(1): 11-25.

Fracro, F., and Echeverrigaray, S. 2001. Micropropagation of Cunila galoides, a popular medicinal plant of South Brazil. Plant Cell Tiss Org Cult. 64: 14.

Fraternale, D., Giamperi, L., Ricci, D., and Rocchi, M. B. L. 2002. Micropropagation of Bupleurum fruticosum: The effect of triacontanol. Plant Cell Tissue Organ Cult. 69(2): 135- 140.
Kumari, M. 2012. Evaluation of methanolic extracts of in vitro grown Tinospora cordifolia (willd) for antibacterial activities. Asian J Pharm Clin Res. 5(3):172-175.

Mittal, J., and Sharma, M. M.2017. Enhanced production of berberine in In vitro regenerated cell of Tinospora cordifolia and its analysis through LCMS QToF. 3Biotech. 7(1):25.

Mohapatra, P. P., Batra, V. K., Kajla, S., Poonia, A. K., and Kumar, N.M. 2016. Effect of different growth regulators on in vitro micro-propagation of Kufri Frysona. Applied and natural science foundation. 8(2): 535-540.

Mandal, J. 2013.In Vitro Flowering and Micropropagation of Hyptis suaveolens (Linn.) Poit.— An Important Medicinal Herb. Journal of herbs, spices and medicinal plants. 19(3): 233-247.

Martin, G., Geetha, S., Raghu, P. A. V., Balachandran, I., Ravindran, P. N. 2005. Micropropagation of Holarrhena pubescens. J Trop MedPlants. 6(1):111-115.

Massot, B., Milesi, S.,Gontier, E., Bourgaud, F., and Guckert, A.2000. Optimized culture conditions for the production of furanocoumarins by micropropagated shoots of Rutagraveolens. Plant Cell Tissue Organ Cult. 62(1):11-19.

Martin, K. P. 2003. Rapid in vitro multiplication and ex vitro rooting of Rotula aquatica Lour., a rare rhoeophytic woody medicinal plant. Plant Cell Rep. 21(5): 415-420.

McCartan, S. A., and Van Staden, J. 1999. Micro propagation of members of the Hyacinthaceae with medicinal and ornamental potential. A review. South Afr. J. Bot. 65(5\&60: 361-369.

McCartan, S. A., and Van Staden, J. 2002. Micro propagation of Scilla kraussii 
and Scilla dracomontana. South Afr. J. Bot. 68(2): 223-225.

McCartan, S. A., and Van Staden, J. 2003. Micro propagation of the endangered Kniphofia leucocephala Baijnath. In vitro Cellular DevBiol Plant. 39(5): 496-499.

Mycock, D. J., Watt, M. P., Hannweg, K.F., Naicker, K., Makwarela, M., and Berjak, P.1997. Somatic embryo genesis of two indigenous South African Haworthia spp. (H. limifolia and H. koelmaniorum). South Afr. J. Bot. 63(6): 345-350.

Rout, G.R. 2005. Micropropagation of Clitoria ternatea. Linn. (Fabaceae)An important medicinal plant. In Vitro Cell Dev Biol Plant. 41(4):516-519.

Sarker, R. H., Islam, M.R., and Hoque, M.I. 1997. In vitro propagation of neem (Azadirachta indica A. Juss.) plant from seedling explants. Plant tissue Cult.7:125-133.

Sharma, N., Chandel, K. P. S., and Paul, A. 1993. In vitro propagation of Gentiana kurroo: an indigenous threatened plant of medicinal importance. Plant Cell Tiss Org Cult. 34(3): 307-309.

Sharma, N., and Patni, V. 2012. Grewia tenax (Frosk.) Fiori.- A traditional medicinal plant with enormous economic prospectives. Asian J Pharm Clin Res.2. 5(3): 28-32.

Shibli, A. R., Ajlouni, M. M., Shatnawi, A. M., and Abdullah, A.B. 1999. An effective method for in vitro production of disease - free carnation (Dianthus caryophyllus CV. Balady). Plant Tissue Cult. 9:159-166.

Thorpe, T. A. 1982. In Techniques and Applications of Plant Cell and Tissue Culture to Agriculture and Industry (eds Tomes, D. T. et al.,), University of Guelph, Ontario. Pp. 115-138.

Vanisree, M., Lee, C. Y., Lo, S.F., Nalawade, S. M. 2004. Studies on the production of some important secondary metabolites from medicinal plants by plant tissue cultures. Bot Bull Acad Sin. 45:1-22.

\section{How to cite this article:}

Anika Malik and Aditi Arya. 2019. Studies on Effect of Hormone on in vitro Regeneration of Tinospora cordifolia. Int.J.Curr.Microbiol.App.Sci. 8(10): 1386-1393. doi: https://doi.org/10.20546/ijcmas.2019.810.162 